\title{
Reaching the 21st century students in the United Arab Emirates: using Ethnomathematics through \#Innovation
}

\author{
Jason D. Johnson \\ Darryl Corey
}

\begin{abstract}
We in the College of Education at Zayed University are committed to excellence. With that in mind, we developed a very ambitious project to create an IOS math app to encourage grade six Emirati students to engage with mathematics. Additionally, our project aimed to provide Emirati students (boys and girls) opportunities to explore mathematics based on modules grounded in the Emirati culture. More specifically, the IOS math app contained three modules - Henna (in Arabic حنة ), Prayer Beads (مسبحة), and Bamboo Baskets (سلال البامبو). The Henna explored geometric transformations; Prayer Beads investigated patterns in Algebra, and Bamboo Baskets examined circumference, diameter, reading a ruler, and where does pi come from. This paper will provide a detail description and project justifications. Along with a short analysis of the grade six Emirati students' henna designs, as the designs relate to geometric transformations.
\end{abstract}

Keywords: Ethnomathematics. Grade Six. United Arab Emirates. Mobile Learning. Henna.

\section{Alcanzando a los estudiantes del siglo XXI en los Emiratos Árabes \\ Jason D. Johnson \\ Doctor in Mathematics Education by Florida State University. Associate Professor of \\ Unidos: usando las Etnomatemáticas a través de \# Innovación} Mathematics Education by Zayed University. Dubai, United Arab Emirates. (iD) https://orcid.org/0000-0002-3648-6992 \jason.johnson@zu.ac.ae Darryl Corey Doctor in Mathematics Education by Florida State University. Associate Professor and Program Director at School of Teacher Education and Leadership, Radford University. Radford, Virginia, United States. (iD) https://orcid.org/0000-0003-2167-6715 $\bowtie$ dcorey3@radford.edu

Received in 04/09/2019 Accepted in 07/12/2019 Published in 04/03/2020 Emiratí de sexto grado, ya que los diseños se relacionan con transformaciones geométricas.

Resumen: Nosotros en la Facultad de Educación de la Universidad Zayed estamos comprometidos con la excelencia. Con eso en mente, desarrollamos un proyecto muy ambicioso para crear una aplicación de matemáticas IOS para alentar a los estudiantes emiratíes de sexto grado a participar en las matemáticas. Además, nuestro proyecto tenía como objetivo proporcionar a los estudiantes emiratíes (niños y niñas) oportunidades para explorar las matemáticas basadas en módulos basados en la cultura emiratí. Más específicamente, la aplicación matemática IOS contenía tres módulos: henna (en árabe حنة), cuentas de oración (مسبحة) y cestas de bambú (سلال البامبو). La henna exploró las transformaciones geométricas; las cuentas de oración investigaran patrones en álgebra, y las cestas de bambú examinaran la circunferencia, el diámetro, la lectura de una regla y de dónde proviene pi. Este documento proporcionará una descripción detallada y justificaciones del proyecto junto con un breve análisis de los diseños de henna de los Palabras clave: Etnomatemáticas. Grado 6. Emiratos Árabes Unidos. Aprendizaje móvil. Henna.

\section{Alcançando os alunos do século XXI nos Emirados Árabes Unido: usando a Etnomatemática por meio da \# Inovação}

Resumo: Nós da Faculdade de Educação da Universidade de Zayed estamos comprometidos com a excelência. Com isso em mente, desenvolvemos um projeto muito ambicioso para criar um aplicativo de matemática do IOS para incentivar os alunos do sexto ano dos Emirados a se envolverem com a matemática. Além disso, nosso projeto teve como objetivo oferecer aos alunos dos Emirados (meninos e meninas) oportunidades de explorar a matemática com base em módulos fundamentados na cultura dos 
Emirados. Mais especificamente, o aplicativo de matemática do IOS contém três módulos - Henna (em árabe), Prayer Beads (مسبحة) e Bamboo Baskets (سلال البامبو). O Henna explorou transformações geométricas; os Prayer Beads investigaram os padrões em álgebra e as Bamboo Baskets examinaram a circunferência, o diâmetro, a leitura de uma régua e de onde vem o pi. Esse documento fornecerá uma descrição detalhada e as justificativas do projeto juntamente com uma breve análise dos desenhos de hena dos alunos dos Emirados do sexto ano, pois se relacionam a transformações geométricas.

Palavras chave: Etnomatemática. $6^{\circ}$ Ano. Emirados Árabes Unidos. Aprendizagem Móvel. Henna.

\section{Introduction}

Education in the UAE has changed rapidly in the past decade, in order to be a leader in innovative education. Ministry of Education $(\mathrm{MoE})$ initiated several programs to enhance the use of mobile learning in grades PreK - 16. Ethnomathematics and mobile learning seemed like a perfect partnership. A project was designed to build an IOS math app that included ethnomathematics modules based on the Emirati culture for grade six Emirati students. The intent of the math app was to provide students with a sense of pride for the Emirati culture and mathematics. The premise of this paper is to describe the project and provide a short analysis of student work for one module.

\section{Ethnomathematics in Middle Eastern and Islamic Cultures}

Mathematics has a deep history in the Middle East and Islamic Culture. Although not realized until recently, Islamic culture has influenced mathematics greatly in the West. In this context, studies of:

(...) number theory formed a continuous tradition and led to the discovery of theorems or problems usually ascribed to Western mathematicians several centuries later - for example, the appearance of Wilson's Theorem in the work of Ibn al-Haytham, Bachet's problem of the weights in al-Khazim, or the summation of the fourth powers of the integers $1,2, \ldots, n$ in the work of the tenth-century mathematician Abu Saqr al-Qabls" (BERGGREN, 1985, p. 11).

The "period from the mid-tenth to the mid-eleventh century was a highly creative period for many of the mathematical disciplines in Islam, one that saw significant advances in arithmetic and algebra, the development of spherical trigonometry, and brilliant contributions to mechanics, optics, and cartography" (BERGGREN, 1985, p. 27-28).

New discoveries continued to be made in number theory throughout the seventeenth century (BERGGREN, 1985). With these discoveries our understanding about the creation and progression of Western mathematics needs to be amended. Islamic mathematicians discovered many breakthroughs in mathematics prior to Western mathematicians. 
Furthermore, the teaching of ethnomathematics in the Middle East and its history could encourage student mathematical achievement. Instead of learning mathematics of the West, they'd be learning their native mathematics.

Several issues have arisen in Islamic mathematics curriculum, being that students across the Middle East and North Africa (MENA) are drastically behind the rest of the world. This is in part because of low quality education, but could also stem from low parental involvement, and a lack of connection and application to the "real world" (JURAK \& SHAHIN, 1999; AMIT \& QOUDAR, 2017).

Modern technology and new math curricula have discouraged parents, who learned in a more traditional way, to engage in their children's school work. Amit \& Qoudar (2017) stated that "Integrating cultural elements into the mathematics curriculum encouraged the students' family members to become actively involved in their school work, and even to declare, for the first time, that the teacher is smart" (p. 48).

In this context, "while students whose families do not see their studies as relevant may well find it easier to drop out and go to work, students whose families are involved and invested in their schooling may find it easier to persevere" (AMIT \& QOUDAR, 2017, p. 28). Muslim students in a Dutch school seemed to be more motivated, as well as having their parents and grandparents involved in their homework, while creating a Persian mosaic using Mathematical concepts, which is a key component supporting the use of ethnomathematics (KARSSENBERG, 2014).

One issue that arises in middle-eastern cultures is the connection from school mathematics to the real world mathematics. After interviews with young kids who were vendors in Beirut, Jurak \& Shahin (1999) found that these kids knew how to compute complicated math problems if asked in a way that a vendor would hear it but could not compute the same problems using a formula and pencil and paper.

This demonstrates a need for more comprehensive and cultural based problems to be able to connect mathematics concepts to student understanding. Additionally, this problem may originate from the lack of traditional educational opportunities for many in the Middle East. Illiteracy rates in the Middle East are high. Female literacy is 44 percent, while men is 68 percent (MARSH et al., 2014).

For those who do have the opportunity, using ethnomathematics in the classroom makes mathematics more relevant and applicable for students. Utilizing ethnomathematics creates an environment for students to understand their cultural and historical background (KARSSENBERG, 2014). 
Furthermore, the potential benefits of teaching ethnomathematics in schools can affect the future careers of some students in a variety of ways. For instance, in an attempt to protect personal data on computers, ethnomathematics found in Al-Qur'an, Al-Hadith, and Jawi scripts were used to build ciphers (SHAMSUDIN \& ALINOR, 2015).

\section{Mobile Learning in the Middle East}

Several studies have explore mobile learning in the Middle East. Many of these studies focused on learning outcomes as well as attitudes and perceptions when implementing mobile learning in education. Halaweh (2017) provided reflections on university students' behaviors concerning the use of smartphones in Dubai classrooms.

Halaweh (2017) concluded students found their smartphone to be an indispensable part of their lives, universities policies' and the instructors' must learn to adapt their methods to for mobile technology advancement and the pervasive use of smartphones. Additionally, university policymakers must formulate new policies to regulate, not prevent, the usage of mobile phones in the classroom (Halaweh, 2017).

Dashti and Aldashti (2015) examined students' perceptions toward the use of mobile learning at the College of Basic Education in Kuwait. Questionnaires were distributed to 300 undergraduate female students. Their results indicated that $80.3 \%$ of students were satisfied with the using mobile devices in their learning, and believe that the devises improved their knowledge of the English language.

Moreover, Alfarani's (2015) investigated the influence of mobile learning on Saudi female teachers in higher education. She found while mobile learning had the potential to enhance collaboration between students, there were also some obstacles which had negative impacts on mobile learning acceptance. Her findings also revealed a resistance to change as well as a negative social cultural concern. She discovered individuals who were strongly connected to Saudi culture were less likely to adapt to mobile learning (ALFARANI, 2015).

Furthermore, Almutairy, Davies and Dimitriadi (2015) explored the likelihood of integrating mobile learning into Saudi Arabian higher education institutions. Their findings revealed great opportunities for mobile learning and the use of mobile phones increased students' knowledge gains (ALMUTAIRY, DAVIES \& DIMITRIADI, 2015). Al-Fahad's (2009) surveyed students' attitudes and perceptions toward the effectiveness of mobile learning. 186 undergraduate female students were surveyed at King Saud University in Saudi Arabia. The results revealed that mobile learning 
improved students' knowledge retention and enhanced students' learning process.

Similarly, Nassuora (2013) examined students' acceptance of mobile learning in Saudi Arabia. This quantitative study utilized questionnaire results from 80 higher education students. The findings demonstrated that mobile learning had a high level of acceptance among the Saudi students.

Another study surveyed 131 undergraduate students at a Saudi Arabian university. The results revealed that more than $75 \%$ students had positive attitudes towards mobile learning due to the flexibility of and timing of the learning methods, and improved communications among learners (CHANCHARY \& ISLAM, 2011).

Tuparov, Al-Sabri and Tuparova (2015) conducted a pilot study to investigate higher education students' attitude and readiness concerning the implementation of mobile learning in the Republic of Yemen. They concluded that while students were familiar with personal uses of smartphones, the students were unfamiliar with how to use smartphones for active learning. They also determined that while students had positives attitudes towards the use of mobile learning in their education, the universities in the Yemen did not offer sufficient mobile learning resources.

Sociocultural considerations are also significant factors when integrating all forms of technology usage in any educational settings. Baker, Al-Gahtani, and Hubona (2007) provided an example of how cultural traditions relating to gender in Saudi Arabia can impact attitudes toward mobile learning. They discovered that gender segregation in the Saudi education had a significant impact on the attitudes and perceptions toward the use of mobile devices in educational settings.

Another study (AI-KANDARI, AI-HUNAIYYAN \& ALHAJRI, 2016) sought to understand the effect of culture on Instagram use by male and female students in Kuwaiti higher education institutions. Their findings indicate males were more likely to reveal personal information than females. The rationale for the result was due to Kuwaiti conservative norms and traditions.

For the premise of this paper, a larger study was designed, using Bayesian Networks as a framework, to explore the educational implications of an IOS math app that used ethnomathematics modules based on the Emirati culture designed for grade six Emirati students in the UAE. This paper will explore the grade six Emirati students' henna designs, as the designs relate to geometric transformations. Additionally, the project design and justifications are considered. 


\section{The Project}

The team was ambitious to develop and build an IOS math app for grade six Emirati students. The app would have several modules that provide the Emirati student with ethnomathematics problems based on the Emirati culture. In other words, students would be able to explore mathematics through the Emirati culture or examine the Emirati culture through mathematics.

For this to be accomplished, the first and third authors held several brainstorming sessions to generate Emirati cultural examples. Over twenty examples were identified. In the end, three Emirati cultural examples were agreed upon for the math app: henna, prayer breads, and bamboo baskets (Figure 1).

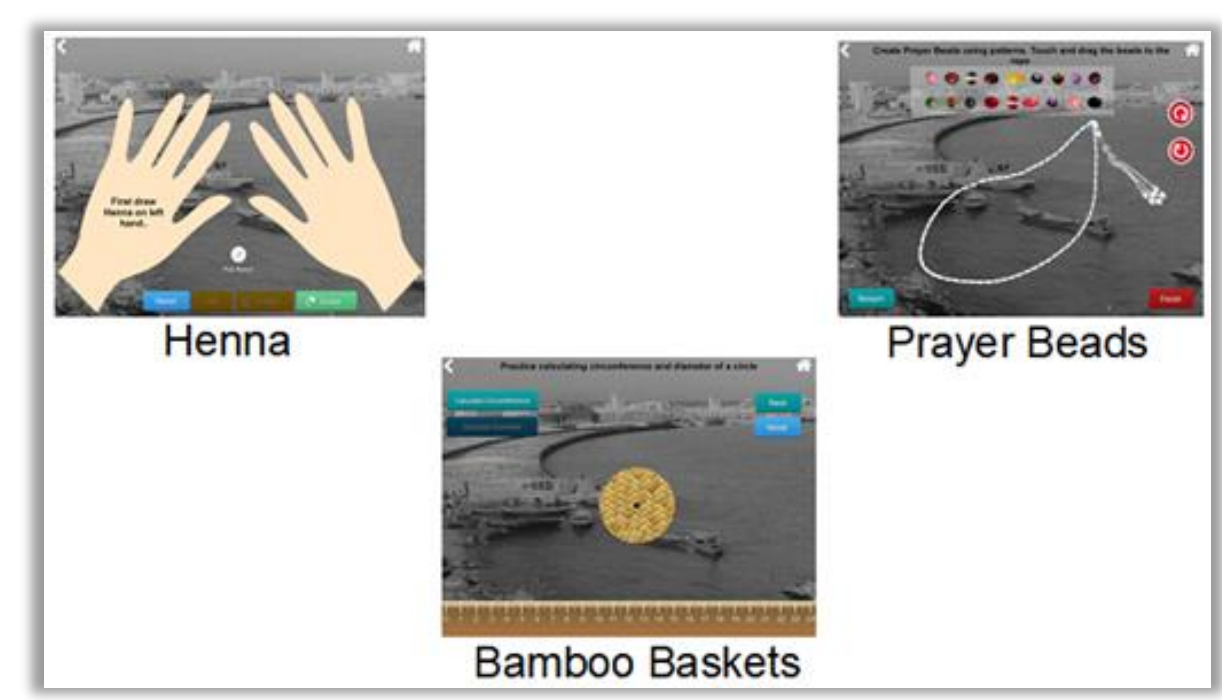

Figure 1: Emirati cultural example used in the IOS math app (Authors' personal file)

The rationale for selecting these three Emirati cultural examples was based on the popularity of the examples have in the UAE. Most students would have seen their family and/or friends use the three cultural examples - i.e., weddings, birthdays etc. Additionally, some students' could have family and/or friends who create the cultural examples - i.e., henna, prayer beads, and bamboo baskets.

Based on the selected Emirati cultural examples, possible mathematics topics needed to be identified. Since the math app was targeted for grade six Emirati students, such mathematics concepts would be explored: transformation geometry, patterns in algebra, diameter/circumference relationship, and where does Pi come from? (Figure 2). 


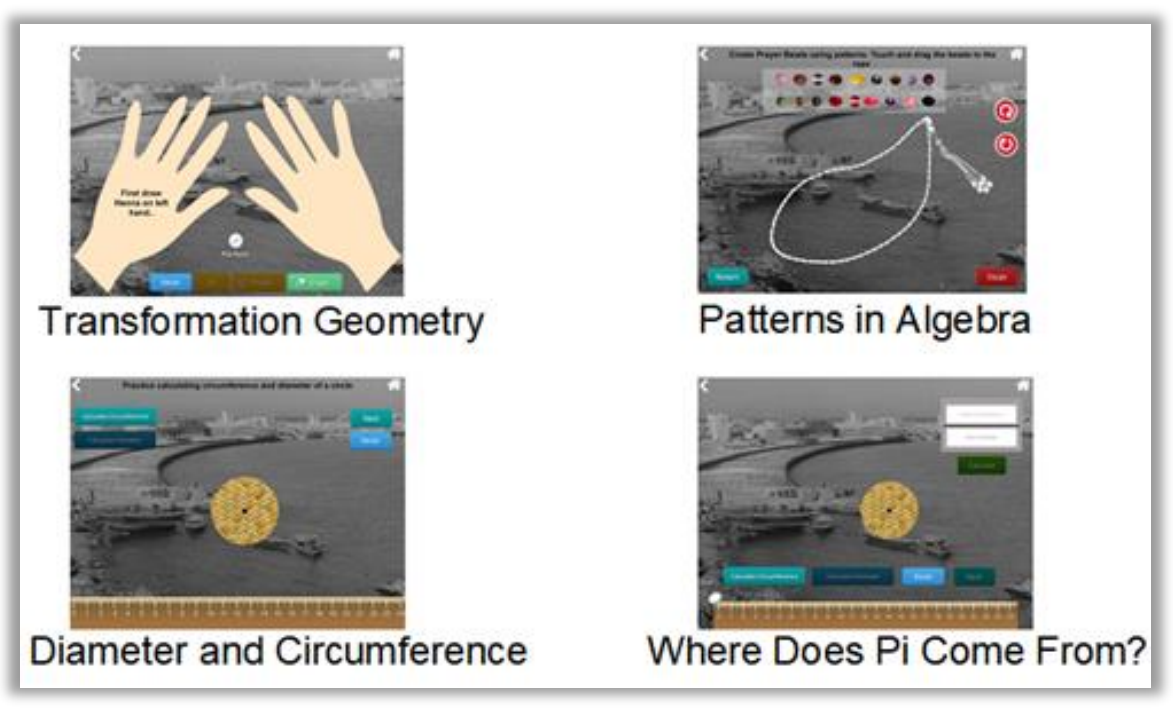

Figure 2: mathematics content used in the IOS math app (Authors' personal file)

Before the layout of the math app could be determined, there was a need to gather input from grade six teachers in the UAE. With that said, a session was held at the 2013 UAE Math Day - an annual conference for mathematics and mathematics education researchers in the UAE to discuss the math app. In the session, teachers were given ample time to provide input into the math app.

Surprisingly, teachers provided several suggestions; such as, provide students with a game and various problems to solve; rather than just an educational app - an app used for teaching purposes. Another suggestion was that the app should be mostly in English. The rationale for using English was encouraged by the teachers, who wanted the app to reinforce the mathematics terms in English. Furthermore, in the session, teachers seemed extremely eager for the completion of the app. In the end, all teacher suggestions were implemented in the math app.

Each module contained four parts. Part one, in Arabic, a video that provides an historical narrative to celebrate the cultural examples - i.e., henna, prayer beads, and bamboo baskets. The team wanted the entire IOS math app to be in Arabic, however, due to the teachers request, the team was encouraged to use English. The rationale for the video in Arabic and not English was to honor the Arabic language.

Since the majority of the IOS math app was in English, the team wanted some feature to be in the Arabic language; and the video was the only option. The video hints to the inclusion of mathematical thinking of the Emirati person doing such cultural work. However, leaving the student to make such a connection. For instance, the henna, the female Emirati henna maker uses transformations, typically associated with Western mathematics, without using such mathematical terms as translation or rotation. How does the henna maker know rotation and translation? She 
may not know or use these mathematical terms but she is able to model them while creating the henna.

Part two, each module contained pictures of the Emirati cultural example. If the math app is used with students who are not familiar with such examples, students could view pictures. In part three, each module has an exploration of mathematics that could be used with the Emirati cultural example. In other words, students either explore the mathematics using the Emirati cultural example or explore the Emirati cultural example using mathematics.

At this point, the math app does not make the connection of Emirati cultural example to specific mathematics topics - or mathematics to the Emirati cultural example. Part four, each module allows students the opportunity to test their new knowledge by completing several examples - this could be in the form of a game.

Last, part five, each module provides students an opportunity to design the Emirati cultural example. Meaning, students actually create the Emirati cultural example - i.e., henna, prayer beads, and bamboo baskets - using creativity.

\section{Significance to the Emirati Culture}

A deliberate concern was made to not make the IOS math app seem superficial to the larger community. The intent of the IOS math app was to provide grade six Emirati students with an opportunity to view their culture in the mathematics — or to view mathematics in their culture. In other words, we wanted the students to make connections to either: culture and mathematics or mathematics and culture.

For instance, Emirati students have seen henna at weddings and special events. After using the math app, when Emirati students view a henna design, they may think about geometry transformations. In the end, our intent was to honor the Emirati culture and allow grade six Emirati students an opportunity to make connections to their culture through a mathematical lens - or make connections to mathematics through an Emirati cultural lens.

\section{Student Henna Designs}

Since henna designs are solely for females in the UAE, boys were not allowed to participate in the henna module. Again, the henna module included: a video showcasing the historical implications, exploration of the types of transformations, game, and students create henna. A 
further discussion will explore student created henna designs.

\section{* Henna Design - Activity 1}

Before Activity 1, students watched the henna video and explored the various transformations identified in the math app. The students even completed the game for henna students were required to identify the transformation based on henna design on a right- and lefthead.

In other words, students were shown several pictures of henna design on two hands and students were to determine which transformation was displayed in the picture. Once the video and the game were completed, for Activity 1, students were asked to create a henna on the left-hand. Then, students created the same henna on the right-hand (see Figure 3).

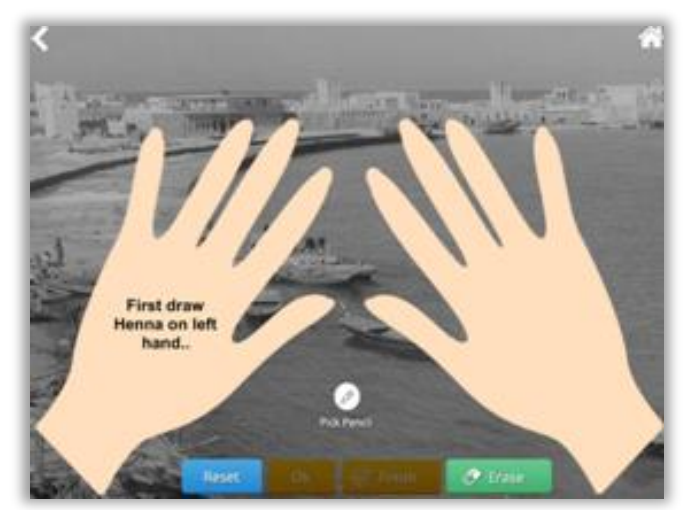

Figure 3: Henna module - Students create henna in the IOS math app (Authors' personal file)

A research team member facilitated the session, as students were diligently creating their henna designs, the facilitator purposely made no mention of the types of transformations, as he walked about the room to view and assist students' henna creations.

After students completed their henna design, students were asked to present their work. During student presentations, students were asked to identify the type of transformation(s) used in their design.

The purpose for Activity 1 was to allow students an opportunity to create henna designs and not focus on the geometric transformations, until the completion of the henna design and during the presentation.

Based on student work, it is apparent that students were able to create henna designs. Again, the researcher facilitator did not remind students of the geometric transformations. However, when students presented their henna design, they were able to correctly identify the geometric 


\section{revemop}

transformation(s).

For the purpose of Activity 1, the intent was for students to use the geometric transformations at an introductory level. The team wanted the students to be able to correctly identify, for example, a rotation; instead of a point of rotation - which they level learn at the secondary school level. See Figure 4, for a sample of the Emirati grade six student henna creations.

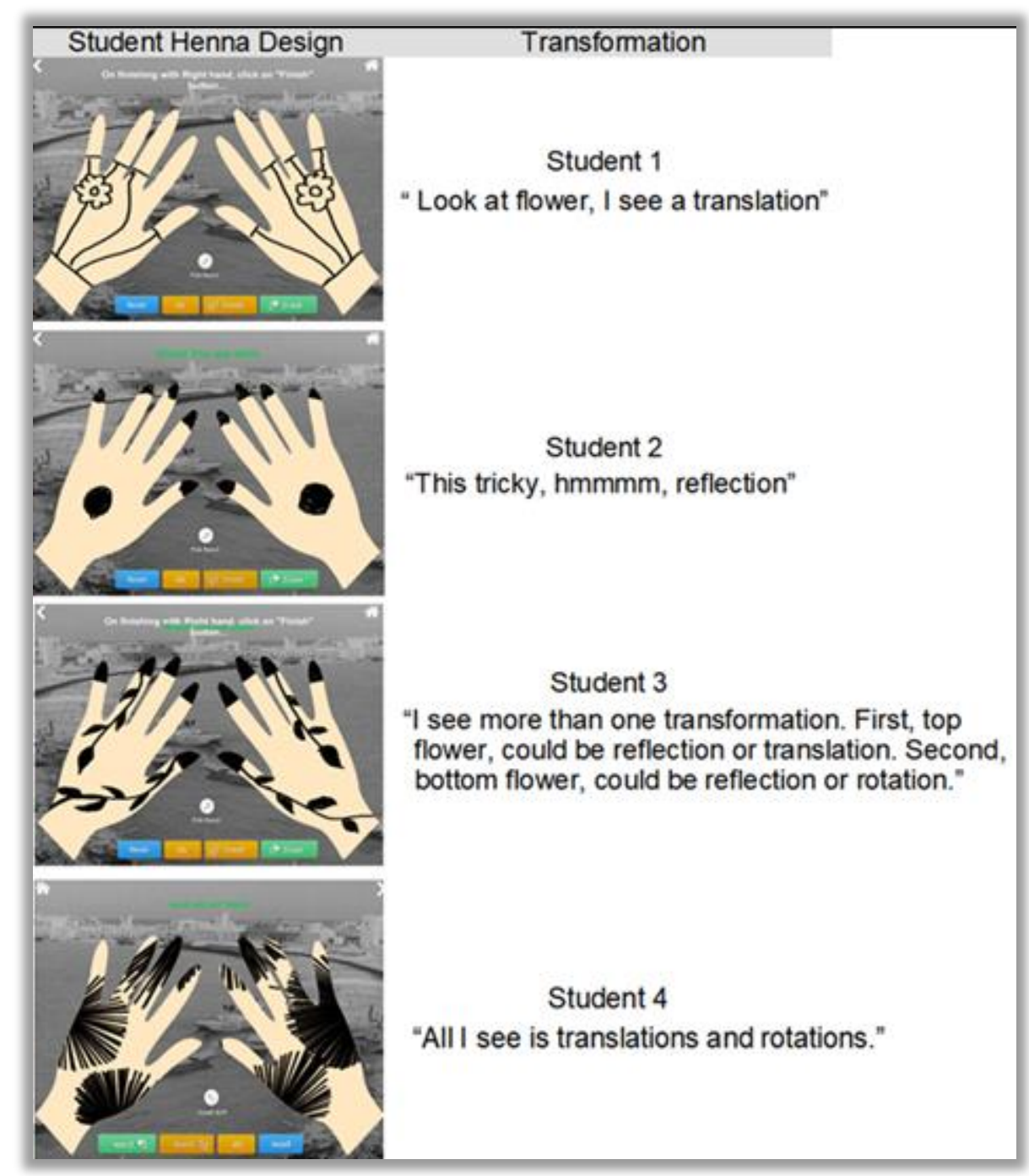

Figure 4: Student henna designs - Activity 1 (Authors' personal file)

In the end, it was clear that students were able to identify geometric transformations in the students' henna designs. Again, the we wanted the grade six Emirati students to use the geometric transformations at an introductory level. It was our attempt to allow grade six Emirati students an opportunity to use their mathematics skills of transformations and henna designs. Based on the henna designs, in Figure 4, students were able to use geometric transformations to create henna designs. 


\section{* Henna Design - Activity 2}

In Activity 2, students were to think about the types of geometric transformations before designing their henna. In other words, students were to use one or several of the types of geometric transformations and model the term(s) in their henna design. Students were then asked to present their henna design and explain which type of geometric transformation(s) were used (Figure 5).

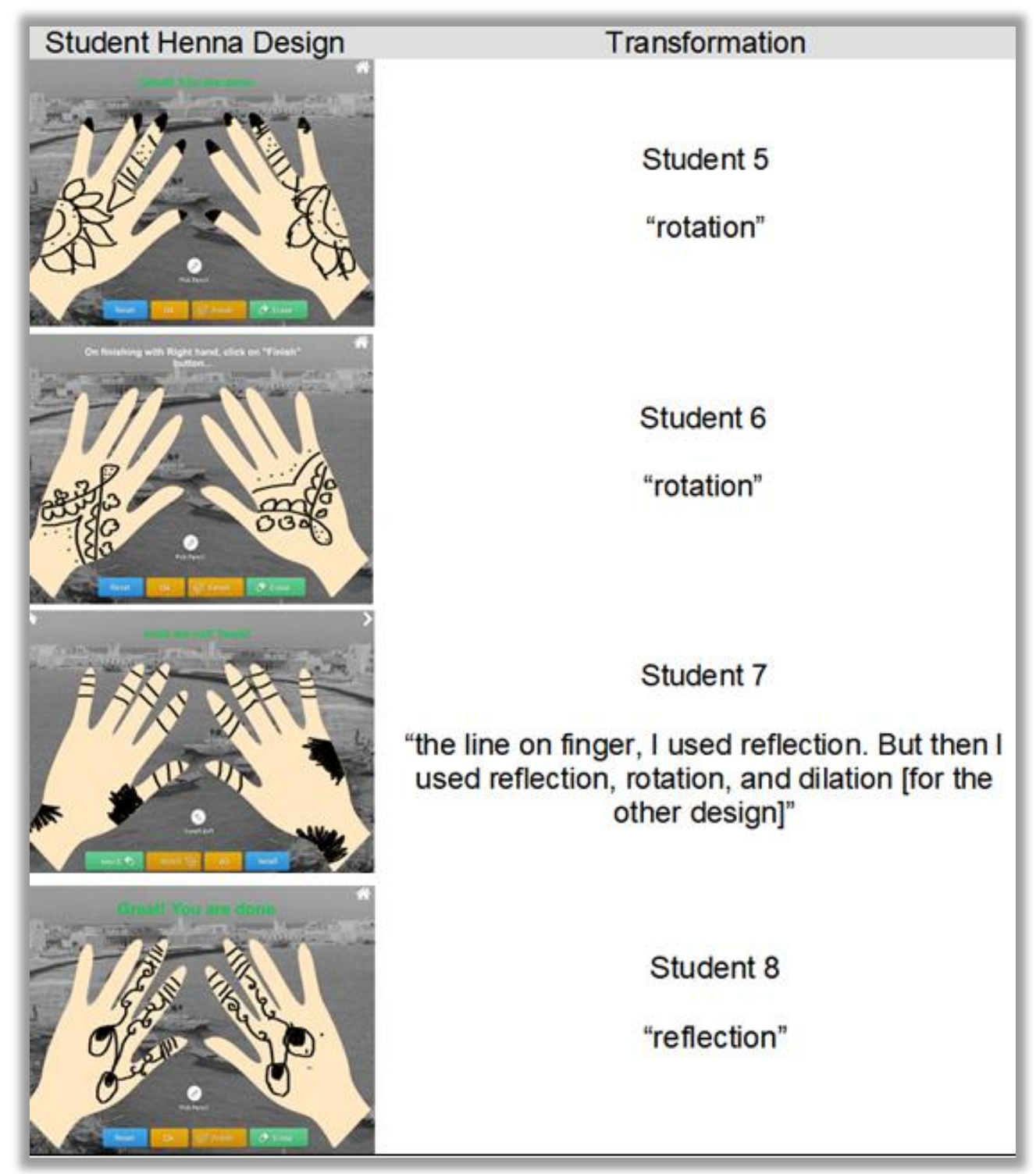

Figure 5: Student henna designs - Activity 2 (Authors' personal file)

Finally, in Activity 2, students were to think of geometric transformations and model such geometric transformations in their henna design. The team wanted students to explore mathematics through the Emirati culture and/or examine the Emirati culture through mathematics.

Again, the team did not explicitly inform students; the goal was for students to make this connection for themselves. Listening to student conversations, it was noticed that students took ownership of either exploring mathematics through the Emirati culture or examine the Emirati 
culture through mathematics.

\section{Conclusion}

The purpose of this paper was to showcase an IOS app, which used mathematical modules based on the UAE culture. No app of its kind is currently available to help Emirati students make sense of mathematics using the Emirati culture. The IOS math app contained various modules to allow students opportunities to explore mathematics. The research team has additional IOS math apps based on the Emirati culture being developed. Such apps will continue to provide grade six Emirati students with an alternative to explore mathematics.

he UAE is rich in cultural developments that lend themselves to ethnomathematics. For instance, the Emirati fisher-men using dome-like cage to catch fish. How does the fisher-man know how big to make the cage? How do fish enter the dome but unable to exit?

Also, pearl drivers able to locate the directions of pearls on the Arabian Gulf floor and determine the depth and amount of time one must hold their breath to collect the pearls. These are just two examples, although are a plethora of ethnomathematics examples that exist in the United Arab Emirates which highlight the historical use of mathematics by the Emirati people.

\section{References}

Al-FAHAD, Fahad N. Students' attitudes and perceptions towards the effectiveness of mobile learning in King Saud University, Saudi Arabia. Turkish Online Journal of Educational Technology, v. 8, n. 2, p. 111-119, apr. 2009.

ALFARANI, Leena Ahmad. Influences on the adoption of mobile learning in Saudi women teachers in higher education. International Journal of Interactive Mobile Technologies, v. 9, n. 2, p. 58-62, mar. 2015.

Al-KANDARI, Ali J.; Al-HUNAIYYAN, Ahmed A.; Al-HAJRI, Rana. The influence of culture on instagram use. Journal of Advances in Information Technology, v. 7, n. 1, p. 54-57, fev. 2016.

ALMUTAIRY, Sulaiman; DAVIES, Trevor; DIMITRIADI, Yota. The readiness of applying mobile learning among Saudi Arabian students at higher education. International Journal of Interactive Mobile Technologies, v. 9, n. 3, p. 33-36, jan. 2015.

AMIT, Miriam; QOUDER, Fouze Abu. Weaving culture and mathematics in the classroom: the case of Bedouin ethnomathematics. In: ROSA Milton; SHIRLEY Lawrence; GAVARRETE Maria, ALANGUI, Wilfredo (Ed.). Ethnomathematics and its Diverse Approaches for Mathematics Education. Switzerland, Hamburg/Germany: Springer International Publishing, 2017, p. 23-50. 
BAKER, Elizabeth White; AI-GAHTANI, Said S; HUBONA, Geoffrey S. The effects of gender and age on new technology implementation in a developing country: testing the theory of planned behavior (TPB). Information Technology \& People, v. 20, n. 4, p. 352-375, 2017.

BERGGREN, John Lennart. History of mathematics in the Islamic World: the present state of art. Middle East Studies Association Bulletin, v. 19, n. 1, p. 9-33, jul. 1985.

CHANCHARY Farah Habib; ISLAM, Samiul. Mobile learning in Saudi Arabia - prospects and challenges, In: International Arab Conference on Information Technology (ACIT). Proceedings... Riyadh, Saudi Arabia, 2011, p. 176-182.

DASHTI, Fatimah; ALDASHTI, Abdulmohsen. EFL college students' attitudes towards mobile learning. International Education Studies, v. 8, n. 8, p. 13-20, 2015.

HALAWEH, Mohanad. Using mobile technology in the classroom: a reflection based on teaching experience in UAE. TechTrends: Linking Research \& Practice to Improve Learning, v. 61, n. 3, 218222, may. 2017.

JURDAK, Murad; SHAHIN, Iman. An ethnographic study of the computational strategies of a group of young street vendors in Beirut. Educational Studies in Mathematics, v. 40, n. 2, p. 155-172, 1999.

KARSSENBURG, Goosen. Learning geometry by designing Persian mosaics. For the Learning of Mathematics, v. 34, n. 1, p. 43-49, mar. 2014.

MARSH, Herbert W.; ABDULJABBAR, Adel Salah; PARKER, Philip D., MORIN, Alexandre J. S.; ABDELFATTAH, Faisal; NAGENGAST, Benjamin. The big-fish-little-pond effect in mathematics: A cross-cultural comparison of U.S. and Saudi Arabian TIMSS responses. Journal of Cross-Cultural Psychology, v. 45, n. 5, 777-804, jan. 2014.

NASSUORA, Ayman Bassam. Students acceptance of mobile learning for higher education in Saudi Arabia. International Journal of Learning Management Systems, v. 1, n. 1, p. 1-9, 2013.

SHAMSUDIN, A Faizul; ALINOR, Mohammad. Development of Ethno-mathematics of Al-Qur'an, Al-Hadith, and Jawi Scripts for Computer Security. In: OMAR, Roaimah; BAHROM, Hasan; DE MELLO, Geraldine. (Ed.). Islamic Perspectives Relating To Business, Arts, Culture And Communication. Singapore: Springer, 2015, p. 3-12.

TUPAROV, Georgi; AI-SABRI, Abdulrahman; TUPAROVA, Daniela. Students' readiness for mobile learning in Republic of Yemen - a pilot study. In: INTERNATIONAL CONFERENCE ON INTERACTIVE MOBILE COMMUNICATION TECHNOLOGIES AND LEARNING. Thessaloniki, Greece, nov. 2015. 